\title{
THE MODE OF ACTION OF DRUGS BLOCKING GANGLIONIC TRANSMISSION IN THE RAT
}

\author{
BY
}

\author{
D. G. SHAND
}

From the Department of Pharmacology, Medical College of St. Bartholomew's Hospital, London, E.C.1

(Received May 18, 1964)

Quilliam \& Shand (1964) found that the ganglion-blocking action of drugs in the rat can be either highly selective, moderately selective or nonselective. As it appeared that the mode of block produced by drugs within the same selectivity group was not always precisely the same, the present work was carried out to investigate these differences.

\section{METHODS}

The isolated superior cervical ganglion preparation of the rat was used in the manner described by Quilliam \& Shand (1964). The ganglion, together with the pre- and postganglionic nerves, was excised, the connective tissue sheath removed and the preparation mounted horizontally in a bath of Krebs solution at $30^{\circ} \mathrm{C}$ equilibrated with a mixture of $95 \%$ oxygen and $5 \%$ carbon dioxide. The preganglionic nerve could be stimulated through a pair of platinum electrodes at 6 shocks/min and the ganglionic action potential recorded from a pair of nonpolarizable silver-silver chloride-agar saline electrodes, one on the ganglion and the other on the cut end of the postganglionic nerve. The recording electrodes were connected to a DC amplifier. The potentials were displayed on a cathode-ray oscilloscope. To record, the preparation was raised above the fluid level, giving moist chamber conditions, and the action potential in response to the third stimulus was photographed.

In some experiments the depolarizing action of acetylcholine was measured using the moving fluid electrode technique of Pascoe (1956), by which the potential at any point along the ganglion can be measured relative to the cut end of the postganglionic nerve, using a space base in the oscilloscope.

The effects of the following drugs were observed: acetylcholine chloride (Roche), hexamethonium chloride (Geigy), tetraethylammonium bromide (B.D.H.), tubocurarine chloride and bretylium tosylate (Burroughs Wellcome), atropine sulphate (Samoore), amylobarbitone sodium (Boots), methylpentynol and methylpentynol carbamate (British Schering), mephenesin (B.D.H.), paraldehyde (B.D.H.), benactyzine hydrochloride (Levanol, I.C.I.), procaine hydrochloride (Samoore), tetramethylammonium bromide (B.D.H.) and nicotine hydrogen tartrate (Samoore).

Unless otherwise stated the doses are given as the salts.

\section{RESULTS}

\section{Effects on the form of the ganglionic action potential}

Throughout drugs were added to the bath in a cumulative fashion, each dose being in contact with the preparation for $5 \mathrm{~min}$. This allowed rapid comparison and the exposure time was considered sufficient for equilibration (Quilliam \& Shand, 1964). While all the drugs used blocked the spike component of the ganglionic action potential, increasing concentrations produced different effects on the ganglionic afterpotentials. The depolarizing 
agents, nicotine, tetramethylammonium, carbachol and acetylcholine, had qualitatively the same action as that described by Eccles (1956) on the isolated superior cervical ganglion of the rabbit and by Paton \& Perry (1953) for acetylcholine, tetramethylammonium and nicotine on the intact ganglion of the cat. The effect of nicotine was typical and is shown in Fig. 1. As the amplifier used was DC, all upward shifts of the baseline indicated a depolarization of the ganglion relative to the cut end of the postganglionic nerve. With a low

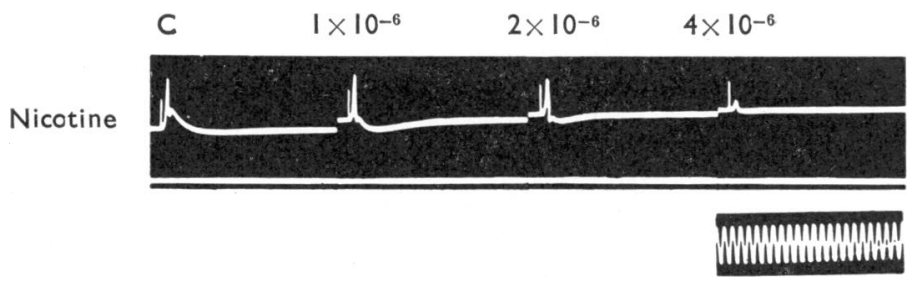

Fig. 1. Effects of nicotine on the ganglionic action potential. The potentials recorded were in response to single maximal stimuli to the preganglionic nerve. $\mathrm{C}$ indicates control response. Cumulative doses of nicotine were added to the bath and records were taken after 5-min exposure. Drug concentrations are shown above each response. An upward shift of the baseline relative to the lower trace (reference beam) indicates a depolarization of the ganglion. Calibration, 25 cycles/sec with an amplitude equivalent to $2.5 \mathrm{mV}$. The changes in the shape of the ganglionic action potential are typical not only of the action of nicotine but also of the other depolarizing drugs, tetramethylammonium, carbachol and acetylcholine. Initially $\left(1 \times 10^{-6}\right)$ the $N$ wave was decreased and the $P$ wave augmented, with little depression of the spike. Then $\left(2 \times 10^{-6}\right)$ the $\mathrm{P}$ wave was shortened and both the $\mathrm{N}$ wave and the spike were further depressed. Finally $\left(4 \times 10^{-6}\right)$ all the potentials became markedly reduced as full block of transmission was approached.

concentration $\left(1 \times 10^{-6}\right)$, the negative afterpotential ( $\mathrm{N}$ wave) was reduced in size and the positive afterpotential ( $\mathrm{P}$ wave) was augmented with little or no reduction in the height of the spike potential. With greater concentrations, the spike potential was decreased and the $\mathrm{N}$ wave was abolished. The $\mathrm{P}$ wave was first shortened in duration, returning more rapidly to isopotential than with low doses, before being gradually abolished by high drug concentrations $\left(4 \times 10^{-6}\right)$.

Tubocurarine (Fig. $2 a$ ) reduced all the components of the ganglionic action potential equally. At full block, a synaptic potential was obtained which was about 10 to $20 \%$ of the initial spike height or 30 to $50 \%$ of the initial size of the $\mathrm{N}$ wave. This is not illustrated, but the synaptic potential with tubocurarine was the same in form as that produced by tetraethylammonium in Fig. $2 d$. Depolarization was never observed.

The action of tetraethylammonium and bretylium appeared to be midway between those of tubocurarine and nicotine as regards their effects on the shape of the ganglionic potential (Fig. $2 c$ and $d$ ). Initially, as with small doses of the depolarizing agents, the $\mathrm{N}$ wave was decreased and the $\mathbf{P}$ wave increased with only a small decrease in the spike potential. Increase in dosage decreased the $P$ wave and finally produced a synaptic potential very like that seen after tubocurarine. In keeping with their effects on the ganglionic potential, both tetraethylammonium and bretylium caused a modest depolarization of the ganglion. Hexamethonium (Fig. 2b) had much the same action as tubocurarine, but with low doses tended to depress the $\mathrm{N}$ wave and cause slight depolarization, though not to the same extent as did tetraethylammonium. There was a graduated increase in the stimulatory effects, as 
(a) Tubocurarine
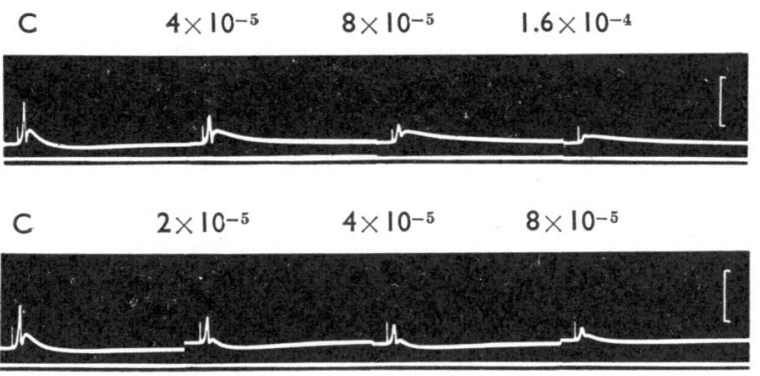

(b) Hexamethonium

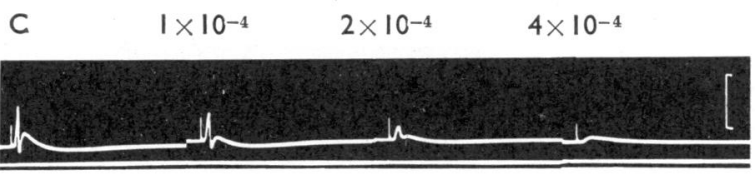

(c) Bretylium

C $\quad 4 \times 10^{-5} \quad 8 \times 10^{-5} \quad 3.2 \times 10^{-4}$

(d) Tetraethylammonium

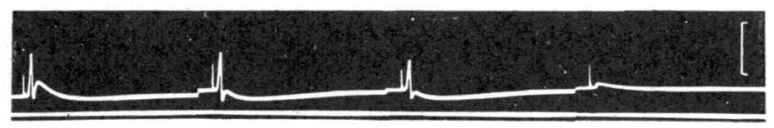

maximinimminum

Fig. 2. Effects of $(a)$ tubocurarine, $(b)$ hexamethonium, $(c)$ bretylium and $(d)$ tetraethylammonium on the ganglionic action potential. Records as in Fig. 1. Cumulative doses of the drugs (concentrations given above traces) added after obtaining control records (C). Calibrations, $25 \mathrm{cycles} / \mathrm{sec}$ and $3 \mathrm{mV}$. Hexamethonium, bretylium and tetraethylammonium produced some depolarization. Low doses (second column of traces) depressed the $\mathrm{N}$ wave and augmented the $\mathrm{P}$ wave with little reduction of spike height as do low doses of the depolarizing drugs (Fig. 1). These stimulatory properties become more marked as one passes from tubocurarine, through hexamethonium to bretylium and tetraethylammonium but were always less marked than those observed with the depolarizing drugs, Pure synaptic potentials are illustrated for tetraethylammonium and bretylium at complete block of transmission, but not for tubocurarine or for hexamethonium, for which block was incomplete.

judged by the depolarization and effect on the shape of the action potential complex, as one passed from tubocurarine, through hexamethonium to bretylium and tetraethylammonium. Amylobarbitone (Fig. 3c), methylpentynol and methylpentynol carbamate had the same effect on the ganglionic potential as tubocurarine, but the time-course of the potential was increased slightly, probably due to a slowing of conduction in the pre- and postganglionic nerve fibres, since these drugs produce some neuronal depression in blocking concentrations (Quilliam \& Shand, 1964).

Increasing doses of procaine (Fig. $3 a$ ) abolished the spike potential and the after-positivity, leaving the $\mathrm{N}$ wave unaltered in amplitude, but increased in duration. The longer timecourse of the $\mathrm{N}$ wave was probably due to the decrease in the $\mathrm{P}$ wave, for these two afterpotentials appear to sum algebraically (Eccles, 1935; Paton \& Perry, 1953). Further increase in dose gradually diminished and finally abolished the $\mathrm{N}$ wave. Paraldehyde and mephenesin produced the same change in shape of the ganglionic action potential as did procaine. 
(a) Procaine

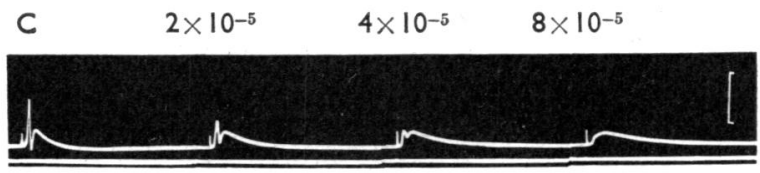

(b) Atropine
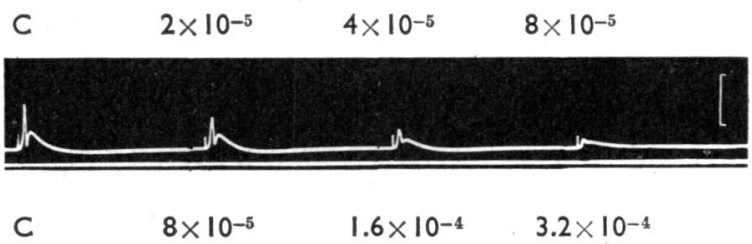

(c) Amylobarbitone

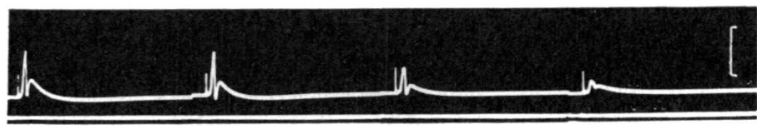

(d) Benactyzine

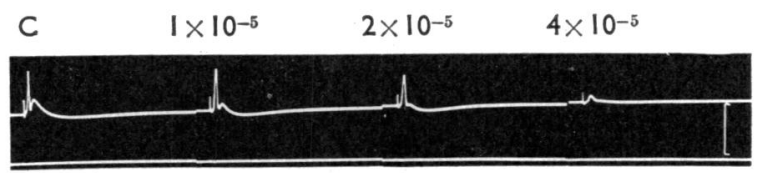

Munuminimin

Fig. 3. Effects of procaine and benactyzine on the ganglionic action potential. Records as for Fig. 1. Control records are indicated by $\mathrm{C}$ and cumulative drug concentrations are given above tracings. Calibrations, 25 cycles/sec and $3 \mathrm{mV}$. Increasing concentrations of procaine gradually reduced and abolished the spike and $\mathbf{P}$ wave, leaving the $\mathrm{N}$ wave. Benactyzine in low concentration reduced the $\mathbf{N}$ wave with little change in the spike or $\mathbf{P}$ wave but further increase in concentration reduced all the potentials. Atropine reduced the spike, $\mathrm{N}$ wave and $\mathrm{P}$ wave leaving a synaptic potential, which had a longer time-course than that seen with curarization. The effects of amylobarbitone were indistinguishable from those of tubocurarine (compare Fig. 1, first row).

With atropine (Fig. $3 b$ ), the spike was reduced and then abolished, leaving a synaptic potential similar to that after tubocurarine, but with a more prolonged time-course. This increased duration may be related to the reduction of the $P$ wave which occurred with low concentrations of atropine, resulting in an increased duration of the $\mathrm{N}$ wave.

Benactyzine (Fig. $3 d$ ) was unique in its effects, for in low dosage it depressed the $\mathrm{N}$ wave with little or no effect on the $\mathrm{P}$ wave. Increase in dose gradually blocked all components of the ganglion action potential.

\section{Relationship between depolarization and block}

With DC amplification, depolarization and block of transmission produced by graded concentrations of drugs can be measured at the same time. Nicotine, tetramethylammonium, acetylcholine, carbachol, tetraethylammonium, bretylium and hexamethonium produced depolarization of the ganglion but the magnitude of the ganglionic block was not always directly related to the amount of depolarization produced. This is illustrated in Fig. 4 in which depolarization, expressed as a percentage of the voltage of the control spike 


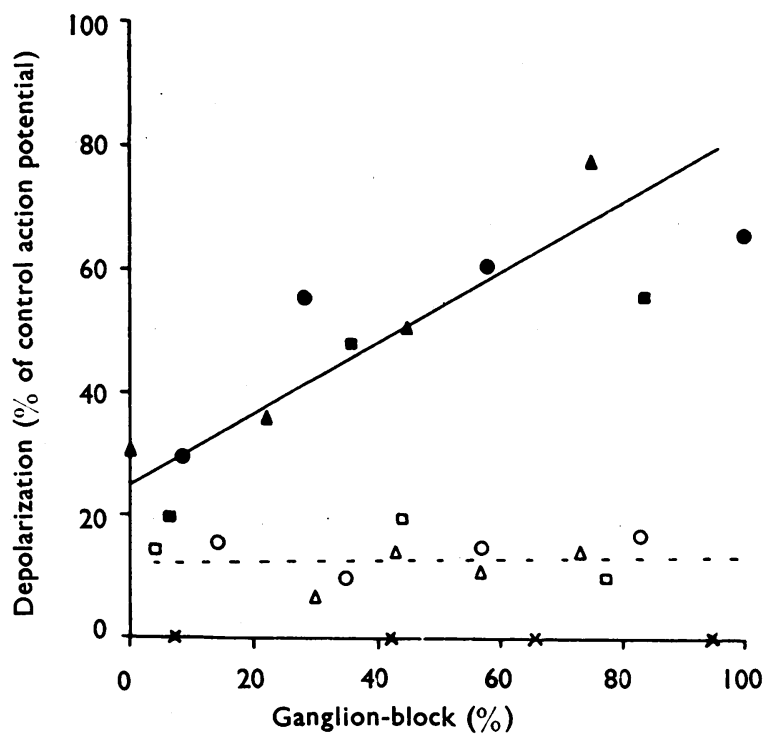

Fig. 4. Relation between depolarization and ganglion-block for nicotine, tetramethylammonium, acetylcholine, tetraethylammonium, bretylium and hexamethonium. Action potentials were recorded as for Fig. 1. One experiment was performed with each drug and the collective results have been plotted. Ordinates : depolarization (measured from shift of baseline) and expressed as a percentage of the height of the control action potential so that different experiments may be compared. Abscissae : percentage block of ganglionic transmission. Filled circles, nicotine; filled triangles, tetramethylammonium; filled squares, acetylcholine; empty circles, tetraethylammonium; empty triangles, hexamethonium; empty squares, bretylium; crosses, tubocurarine (as control). The solid line was drawn by eye as the best fit for the solid symbols and the dotted line as the best fit for the open symbols.

Note: Two groups of drugs can be distinguished: (1) Nicotine, tetramethylammonium and acetylcholine gave values around the steeper solid regression line and depolarization was dosedependent. (2) Tetraethylammonium, hexamethonium and bretylium gave values around the horizontal dotted regression line and depolarization was not dose-dependent.

potential, has been plotted against the percentage block of ganglionic transmission. Points for tubocurarine (crosses), which did not depolarize, have been included as a control. The drugs could be divided into two groups; on the one hand those shown as filled symbols in Fig. 4, namely nicotine, tetramethylammonium, acetylcholine and carbachol (the lastnamed not being included in Fig. 4) and on the other those represented by empty symbols, tetraethylammonium, hexamethonium and bretylium. While tetraethylammonium, bretylium and hexamethonium all caused some depolarization of the ganglion, it was invariably smaller than that produced by the other drugs and, furthermore, increasing the dose of the drug gave very little, if any, increase in the depolarization. The absolute magnitudes of the slight depolarizations produced by these three drugs tended to vary somewhat from experiment to experiment. Although the differences were small, usually the depolarization produced by hexamethonium was least, that by tetraethylammonium was greatest and that by bretylium intermediate. It was concluded, therefore, that the depolarizing activity of these drugs provided no important contribution to their blocking action. 
With nicotine, tetramethylammonium and acetylcholine, a linear relationship existed between depolarization and ganglionic block; with increasing concentrations of these drugs both the depolarization and the block increased proportionately. It was possible, therefore, that, in these short-term experiments, persistent depolarization of the ganglion cell bodies could account for all or, at least, a substantial proportion of the ganglionblocking activity of these drugs.

\section{Antiacetylcholine action}

Apart from nicotine, tetramethylammonium and carbachol which were not investigated, all the drugs in the above experiments depressed the depolarizing activity of acetylcholine when tested with the moving fluid electrode technique of Pascoe (1956). An antiacetylcholine action has not been shown previously for paraldehyde and bretylium. Quantitative measurement of the antiacetylcholine action of the drugs could not be attempted with the present method, since the large doses of acetylcholine necessary to depolarize the ganglion in the presence of blocking doses of the drugs desensitized the preparation even though a concentration of $1 \times 10^{-6}$ of neostigmine was added to the bath fluid. Furthermore, the response of the isolated ganglion to successive, identical doses of acetylcholine alone declined markedly after six to eight doses.

\section{DISCUSSION}

Paton \& Perry (1953) recognized two types of highly selective ganglion-blocking agents, those acting by depolarization and those acting by competition with the transmitter, acetylcholine, for receptor sites on the ganglion cells. The present findings suggest that division between the two types is less sharply defined than they inferred. For instance, we found that both tetraethylammonium and hexamethonium can depolarize the rat ganglion to a moderate extent. Indeed, close inspection of Fig. $7 c$ of the paper of Paton \& Perry (1953) on the effects of tetraethylammonium appears to reveal a slight depolarizing action. In our study, tubocurarine did not depolarize the ganglion cells, but Alonso-de Forida, Cato, Ramirez \& Pardo (1960) have reported that this drug, as well as hexamethonium and tetramethylammonium, caused a slight potentiation of submaximal stimulation through the ciliary and superior cervical ganglia of the intact cat. The potentiation of transmission with tubocurarine which they reported in the superior cervical ganglion was not so marked as that in the ciliary ganglion, which might account for the absence of any depolarization with tubocurarine in our experiments, if indeed tubocurarine has any such effect on the normal rat ganglion.

However, if the relation between depolarization and block is determined over the whole range of blocking concentrations there is little difficulty in recognizing the two types of blocking drug. Depolarizing drugs, such as nicotine, tetramethylammonium and acetylcholine, showed a steep regression line, while hexamethonium and tetraethylammonium did not exhibit a dose-dependent depolarization. It was concluded that the depolarization due to hexamethonium and tetraethylammonium did not contribute to their blocking action, which was probably related to their antiacetylcholine properties, because neither drug blocks nervous conduction (Quilliam \& Shand, 1964) nor prevents acetylcholine liberation from the perfused ganglion (Paton \& Zaimis, 1951; Matthews \& Quilliam, 1964). Tubocurarine also appears to act by acetylcholine antagonism for it also does not affect 
nervous conduction (Quilliam \& Shand, 1964) nor affect acetylcholine liberation (Brown \& Feldberg, 1936). Whether such antiacetylcholine action is truly competitive in the biochemical sense has yet to be determined, but it would seem that the prevention of the transmitter action by occupation of receptors by antagonist molecules provides the most plausible explanation of the action of the competitive ganglion-blocking agents.

The weak depolarizing action of the competitive drugs, hexamethonium and tetraethylammonium, may also be explained in terms of the receptor theory of drug action, for if a drug possesses the molecular configuration required for a good receptor fit so as to deny access to acetylcholine molecules, then it might also be expected to show some weak stimulant (depolarizing) properties. This explanation holds for both the classical " occupation" concept of drug action and for the " rate" hypothesis of Paton (1961) in which the drug action is related to the rate at which a drug molecule combines with the receptor, a natural corollary being that all drugs which combine with the receptor may stimulate (that is, depolarize) at least to some extent.

Tetraethylammonium has an additional stimulant property, namely that of increasing the amplitude of the preganglionic action potential in blocking doses (Quilliam \& Shand, 1964). This is probably related to the increased transmitter output following preganglionic nerve stimulation with tetraethylammonium observed by Douglas \& Lywood (1961) and Matthews \& Quilliam (1964). Collier \& Exley (1963) also found that tetraethylammonium increased the acetylcholine output from the rat phrenic nerve-diaphragm preparation. While an increase in the output of acetylcholine following preganglionic nerve stimulation in the presence of tetraethylammonium could conceivably account for a potentiation of transmission, the depolarization of the ganglion in the resting state is compatible with a direct action on the ganglion cells. In this regard it is interesting to note that tetraethylammonium increased the antidromic spike potential (Quilliam \& Shand, 1964), but this effect was only marked with doses larger than those causing the depolarization described here.

The slight depolarizing action of bretylium in low doses also does not account for its blocking action which has been attributed to a depression of the conduction in the postganglionic nerve (Quilliam \& Shand, 1964), in keeping with its action as an adrenergic neurone blocking agent (Green, 1961). This postganglionic depression could also account for the reduction of depolarization in the higher dosage $\left(4 \times 10^{-4}\right)$ depicted in Fig. $2 c$. Its slight stimulant (depolarizing) action is probably related to its quaternary ammonium structure.

The finding that the ganglionic blocking action of nicotine, tetramethylammonium and acetylcholine was directly related to their depolarizing effect accords with the classification of these agents by Paton \& Perry (1953) as depolarizing ganglion-blocking drugs. Carbachol would appear to act in the same manner. These drugs also produced similar changes in the shape of the ganglionic action potential in the rat as did electrical depolarization of the frog sympathetic ganglion cells in the elegant experiments of Nishi \& Koketsu (1960) which provides further support for the contention that these drugs act by depolarization. However, the work of Paton \& Perry (1953), Lundberg \& Thesleff (1953) and Trendelenberg (1957) in the cat suggests that these drugs may have a dual mode of action and this problem awaits study in the rat. 
Quilliam \& Shand (1964) found that the blocking action of procaine, mephenesin, benactyzine, methylpentynol and methylpentynol carbamate was nonselective and attributed this to a general depression of nervous conduction in the pre- and postganglionic components of the isolated rat superior cervical ganglion preparation. These drugs did not always affect the shape of the action potential in the same way, which implies that their precise modes of action differ. Procaine and mephenesin in low doses abolished the spike potential with only a small reduction of the $\mathrm{N}$ wave. It may be that these drugs prevent the synaptic potential from generating a spike, for in the concentrations giving an isolated $\mathrm{N}$ wave, nervous conduction would be only slightly impaired (Quilliam \& Shand, 1964). These effects and the gradual abolition of the $\mathrm{N}$ wave and nervous conduction with higher doses seem most likely due to membrane stabilization which has been suggested as the mode of action of the local anaesthetic agents by Shanes (1958). Methylpentynol and its carbamate ester reduced all components of the action potential equally and their mode of action is one of general neuronal depression. The stimulant action on the cat ganglion of methylpentynol carbamate reported by Marley \& Paton (1959) and confirmed by Brown \& Quilliam (personal communication) on the cat ganglion was not observed in the present study on the rat. Benactyzine reduced the $\mathrm{N}$ wave considerably before blocking transmission of the spike potential. Although the reason for this is obscure, it may indicate that the synaptic potential is capable of considerable reduction without impairing the generation of the spike, that is, there is a substantial margin of safety for transmission. The antiacetylcholine properties of benactyzine have been suggested as a basis for its central action (Jacobsen, 1958). This does not appear true of the ganglionic synapse.

The moderately selective drugs amylobarbitone and atropine produced much the same changes in shape of the action potential as did tubocurarine and appear to act by acetylcholine antagonism, although with large doses some neuronal depression is added. The observation that paraldehyde produced the same changes in the action potential as the nonselective drugs procaine and mephenesin may be related to the finding of Quilliam \& Shand (1964) that it had the lowest selectivity ratio of their moderately selective drugs.

\section{SUMMARY}

1. The mode of ganglionic block produced by several drugs was investigated by measuring their effects on potentials recorded externally from the isolated superior cervical ganglion of the rat.

2. Nicotine, tetramethylammonium, carbachol and acetylcholine depolarized the ganglion. With 10-min exposures, this depolarization was directly proportional to the degree of ganglionic block.

3. Hexamethonium, tetraethylammonium and bretylium caused a slight depolarization which remained constant despite increasing concentrations which increased the degree of block.

4. The blocking action of hexamethonium and tetraethylammonium was attributed to antiacetylcholine activity and that of bretylium to depression of the postganglionic neurones.

5. Tubocurarine did not depolarize the ganglion.

6. The moderately selective drugs, atropine, amylobarbitone and paraldehyde, and the nonselective drugs, procaine, mephenesin, benactyzine, methylpentynol and methylpentynol 
carbamate, produced various changes in the shape of the ganglionic action potential, demonstrating that drugs in the same selectivity group did not necessarily have precisely the same mode of action.

This work was undertaken in partial fulfilment of the requirements for the degree of Ph.D. in the University of London. I should like to thank Professor J. P. Quilliam for his advice and encouragement throughout, and Mr P. M. G. Bell and Mr K. A. H. Didcock for their kind help. This work was supported by a grant (No. AF 61 (052)-25) from the United States Air Force Office of Scientific Research (OAR).

\section{REFERENCES}

Alonso-de Forida, F., Cato, J., Ramirez, L. \& Pardo, E. G. (1960). Effects of several blocking agents on the sympathetic and parasympathetic postganglionic action potentials. J. Pharmacol. exp. Ther., $129,433-437$.

BROWN, G. L. \& FrLDBERG, W. (1936). Differential paralysis of the superior cervical ganglion. J. Physiol. (Lond.), 86, 10-11P.

COLLIER, B. \& EXLEY, K. A. (1963). Increased output of acetylcholine from motor nerve endings in the presence of tetraethylammonium. J. Physiol. (Lond.), 169, $119 P$.

Douglas, W. W. \& LYwOOD, D. A. (1961). The stimulant effect of TEA on acetylcholine output from the superior cervical ganglion: comparison with barium. Fed. Proc., 20, 324.

EcCles, J. C. (1935). Slow potential waves in the superior cervical ganglion. J. Physiol. (Lond.), 85, 464-501.

ECCLES, R. M. (1956). The effect of nicotine on synaptic transmission in the sympathetic ganglion. J. Pharmacol. exp. Ther., 118, 26-38.

GreEn, A. F. (1961). In Adrenergic Mechanisms, ed. VANE, J. R., Wolstenholme, G. E. W. \& O'ConNor, M., p. 143. London: Churchill.

JACOBSEN, E. (1958). The pharmacological classification of central nervous depressants. J. Pharm. Pharmacol., 10, 273-294.

LUNDBERG, A. \& THESLEFF, S. (1953). Dual action of nicotine on sympathetic ganglion of cat. Acta physiol. scand., 28, 218-223.

MARLEY, E. \& Paton, W. D. M. (1959). The effect of methylpentynol and methylpentynol carbamate on the perfused superior cervical ganglion of the cat. Brit. J. Pharmacol., 14, 303-306.

MATTHEWS, E. K. \& Quilliam, J. P. (1964). Effects of central depressant drugs upon acetylcholine release. Brit. J. Pharmacol., 22, 415-440.

NISHI, S. \& KOKETSU, K. (1960). Electrical properties and activities of single sympathetic neurons in frogs. J. cell. comp. Physiol., 55, 15-30.

PASCOE, J. E. (1956). The effects of acetylcholine and other drugs on the isolated superior cervical ganglion. J. Physiol. (Lond.), 132, 242-255.

Paton, W. D. M. (1961). A theory of drug action based on the rate of drug-receptor combination. Proc. roy. Soc. B, 154, 21-69.

Paton, W. D. M. \& PerRY, W. L. M. (1953). The relationship between depolarizing action and block in the cat's superior cervical ganglion. J. Physiol. (Lond.), 119, 43-57.

Paton, W. D. M. \& Zarmis, E. J. (1951). Paralysis of autonomic ganglia by methonium salts. Brit. J. Pharmacol., 6, 155-168.

Quilliam, J. P. \& Shand, D. G. (1964). The selectivity of drugs blocking ganglionic transmission in the rat. Brit. J. Pharmacol., 23, 273-284.

ShANES, A. M. (1958). Electrochemical aspects of physiological and pharmacological action in excitable cells. Pharmacol. Rev., 10, 59-273.

TRENDELENBERG, U. (1957). Reaktion sympathischer Ganglien während der Ganglienblockade durch Nicotin. Naunyn-Schmiedeberg's Arch. exp. Path. Pharmak., 230, 448-456. 